\title{
REDUCING IMPACT OF POULTRY PRODUCTION IN ENVIRONMENTAL POLLUTION
}

\section{H. Hassan}

Department of Animal Production, National Research Centre, 12622, Dokki, Egypt

The growing world population causes increasing need to animal protein. Increasing poultry production leads to increasing manure and litter. Poultry manure can be utilized as a valuable resource but it is considered a pollutant of water and land. The major potential water contaminants are nitrogen, phosphorus and pathogens. Nitrogen contamination may come from stockpiled manure or manure applied to the land. Increase of phosphorus and organic matter in water can cause rapid growth of algae and decrease oxygen level, which leads to death of fish. There are now enforced legislations in many parts of the world to regulate the quantity of poultry litter permitted on land to limit the potential damage. A major factor in reducing pollution is to keep nutrients in the animal's body rather than excreting them into the environment. This article emphasizes on reducing $N$ and $P$ from poultry manure. Reduction in environmental pollution can be achieved through feed manipulation. Diet formulation based on available nutrients in the ingredients, reducing crude protein or phosphorus supplements and adding enzymes can be applied. Feed manipulation can reduce $N$ and phosphorus excretion by 40 and 55\%, respectively.

Issued by The Egyptian Society of Animal Production 